Article

\title{
Evidence of Leaf Consumption Rate Decrease in Fall Armyworm, Spodoptera frugiperda, Larvae Parasitized by Coccygidium luteum
}

\author{
Lakpo Koku Agboyi ${ }^{1}{ }^{*}$, Samuel Adjei Mensah ${ }^{1}$, Victor Attuquaye Clottey ${ }^{1}$, Patrick Beseh ${ }^{2}$, \\ Raymond Glikpo ${ }^{2}$, Ivan Rwomushana ${ }^{3}{ }^{(1)}$, Roger Day ${ }^{3}{ }^{(1)}$ and Marc Kenis ${ }^{4}$ \\ 1 Centre for Agriculture and Bioscience International (CABI), P.O. Box CT 8630, Cantonments, \\ Accra GA 0376800, Ghana; samuelmensah1a@gmail.com (S.A.M.); v.clottey@cabi.org (V.A.C.) \\ 2 Plant Protection and Regulatory Services Directorate (PPRSD), P.O. Box M37, Accra 00495426, Ghana; \\ pkbeseh@gmail.com (P.B.); glikporaymond@yahoo.com (R.G.) \\ 3 Centre for Agriculture and Bioscience International (CABI), 673 Limuru Road, Muthaiga, P.O. Box 633, \\ Nairobi 00621, Kenya; i.rwomushana@cabi.org (I.R.); r.day@cabi.org (R.D.) \\ 4 Centre for Agriculture and Bioscience International (CABI), 1 Rue des Grillons, 2800 Delémont, Switzerland; \\ m.kenis@cabi.org \\ * Correspondence: 1.agboyi@cabi.org; Tel.: +233-246-723-292
}

Received: 7 July 2019; Accepted: 14 November 2019; Published: 16 November 2019

\begin{abstract}
Biological control is one of the best options for the sustainable management of the invasive maize pest Spodoptera frugiperda in Africa. However, there is limited knowledge of the efficacy of native natural enemies of $S$. frugiperda and their potential use in integrated pest management. The endoparasitoid wasp Coccygidium luteum is one of the natural enemies of $S$. frugiperda in Africa. This study assessed, under laboratory conditions, the effect of $C$. luteum on the leaf consumption rate of its host. Fifty first instar S. frugiperda larvae were exposed to C. luteum for oviposition and the maize leaf consumption rate of parasitized larvae was assessed and compared to 50 unparasitized larvae from the same cohort. Coccygidium luteum completed a generation, from egg to adult emergence, in 16.7 days. The leaf consumption rate of parasitized S. frugiperda larvae declined gradually compared to unparasitized larvae and the overall consumption reduction by parasitized $S$. frugiperda larvae was $89 \%$. Our findings show that $C$. luteum could reduce damage caused by S. frugiperda to maize farms but, prior to its use in biological control programmes, further studies are needed to assess potential parasitism rates in field conditions and develop a cost-effective mass production system.
\end{abstract}

Keywords: maize; fall armyworm; Spodoptera frugiperda; biological control; endoparasitoid; Coccygidium luteum; feeding

\section{Introduction}

Maize is a major staple food for millions of sub-Saharan Africans, and in Ghana it is ranked the first most important cereal crop [1]. However, the sustainable production of maize in Ghana has recently become constrained by the significant damage caused by the invasive fall armyworm, Spodoptera frugiperda (J.E. Smith) (Lepidoptera: Noctuidae), native to the Americas [2,3]. Since its first outbreak in West Africa in 2016, S. frugiperda had spread far and wide to all the sub-Saharan African countries, and to some parts of North Africa and Asia [4]. The rapid spread of S. frugiperda has been facilitated by its high dispersal ability and the wide range of host plants, including grasses and cereals [5-12]. The most hard-hit crop is largely maize, with significant yield and economic losses reported $[9,13]$. Environmental suitability modeling suggests that the pest is going to become resident 
in most places in Africa, making it a significant threat to food security, as maize is the staple food consumed by more than 300 million African smallholder households [2,14].

Emergency action against the pest in several African countries focused primarily on chemical control, a method widely promoted by some governments [15-17]. However, there is varied efficacy of the insecticides currently used in Africa [18], with a risk of insecticide resistance. Resistance to different commonly used pyrethroid, organophosphate and carbamate insecticides has been reported from some S. frugiperda populations in the Americas, especially Florida, from where the strains of the pest found in Africa are thought to have originated $[11,19,20]$. Besides, there is evidence that some commonly used pesticides against $S$. frugiperda remain in soil samples, with possible adverse effects on soil-borne organisms and other non-targeted species [21]. Therefore, an integrated pest management (IPM) approach for S. frugiperda is desirable. In Africa, the main IPM strategy being promoted is based on the judicious use of pesticides and lower risk methods, such as biopesticides, biological control and agronomic practices [22]. In relation to biological control, the major constraint in Africa is not only the limited knowledge on local natural enemies adapting to the pest, but also the capacity of exotic ones to adapt and be efficient under the African climatic conditions and agroecosystems. Given that in an IPM strategy, biological control is an important component [23], field surveys for natural enemies of S. frugiperda were conducted in Ghana in 2018. The survey identified Coccygidium luteum (Brullé) (Hymenoptera: Braconidae) as one of the major natural enemies of S. frugiperda, causing up to $19 \%$ parasitism in some parts of the country [24]. The species was also identified in Kenya and Tanzania as a common parasitoid of $S$. frugiperda, causing up to $9 \%$ parasitism [18]. Coccygidium luteum parasitizes different Lepidoptera species in Africa, such as Condica capensis (Guenée), Crypsotidia mesosema (Hampson), Spodoptera exempta (Walker), Spodoptera exigua (Hübner), Prophantis sp. and Cydia ptychora (Meyrick) [25].

Coccygidium luteum is widely distributed in Africa, as it has previously been recorded in Cameroon, Congo, the Democratic Republic of Congo, Ethiopia, Guinea, Kenya, Madagascar, Mauritius, Mozambique, Namibia, Niger, Nigeria, Rodrigues Island, Réunion, Senegal, Seychelles, Somalia, South Africa, Tanzania and Uganda [25]. It is a solitary koinobiont parasitoid belonging to the braconid sub-family Agathidinae, which contains more than 46 genera worldwide [26,27]. However, species in this sub-family are poorly studied [28], and little is known about their efficacy as biological control agents of insect pests. While a koinobiont parasitoid eventually kills its host, the benefit of biological control by such an agent can be undermined by the voracious feeding of the pest. Therefore, this study aims to assess the efficacy of $C$. luteum in reducing the leaf consumption rate of the $S$. frugiperda larvae on maize, and to understand the role this might play in the IPM of S. frugiperda in Ghana and other parts of Africa where the parasitoid is already present.

\section{Materials and Methods}

\subsection{Insect Collection and Rearing}

Different instars of 154 larvae of S. frugiperda were collected from a maize farm in 2018, in Somanya in the Eastern region of Ghana $\left(06.06225^{\circ} \mathrm{N}, 00.02358^{\circ} \mathrm{W}\right)$. The larvae were held in aerated plastic dishes ( $650 \mathrm{~mL}$ volume) containing a piece of tissue paper and were provided with fresh maize leaves collected in the maize farm, then transported to the biological control laboratory of the Plant Protection and Regulatory Services Directorate in Accra, Ghana. In the laboratory, the larvae were separated into individual cups ( $80 \mathrm{~mL}$ volume) and held under ambient conditions of temperature and relative humidity until the emergence of parasitoid adults or S. frugiperda moths. Adults of $C$. luteum and $S$. frugiperda that emerged were reared in separate aerated plastic cages measuring $18 \mathrm{dm}^{3}$ and $50 \mathrm{dm}^{3}$, respectively. Both insects were provided with $10 \%$ honey solution soaked in cotton wool, which was renewed every two days.

For the mass production of $S$. frugiperda larvae for experimentation, three- to four-week-old maize plants grown in a screenhouse without insecticide treatment were exposed to $S$. frugiperda moths in the 
aerated cage for $24 \mathrm{~h}$. The plants were removed and replaced every $24 \mathrm{~h}$ and the egg masses laid were collected and kept separately in aerated plastic dishes $(650 \mathrm{~mL}$ volume) containing a piece of tissue paper and maize leaves. Hatching larvae were provided with maize leaves until pupal stage. Some of the emerged female moths were paired with males in order to produce subsequent generations of the S. frugiperda larvae.

At each generation of $S$. frugiperda, five to 10 first instar larvae $\left(\mathrm{L}_{1}\right)$ were exposed to each C. luteum female per day. The parasitized S. frugiperda larvae were removed and held in single cups as described above for the field collected larvae.

\subsection{Feeding Tests on S. frugiperda Larvae}

The mean temperature and relative humidity $(\mathrm{RH})$ during this experiment were $32 \pm 2{ }^{\circ} \mathrm{C}$ and $63 \pm 2 \%$, respectively, with a photoperiod of $12 \mathrm{~h}$ light: $12 \mathrm{~h}$ dark. First instar larvae from the sixth generation of laboratory-reared S. frugiperda moths were introduced in aerated cages containing fifth generation C. luteum females mated $24 \mathrm{~h}$ prior to the experiment. A total of 50 one-day-old S. frugiperda $\mathrm{L}_{1}$ were exposed to seven C. luteum females. The behavior of $C$. luteum was observed to detect when parasitism occurred, i.e., when a female had inserted her ovipositor in the host larva. Each larva was removed immediately after being parasitized by the parasitoid and then held in a labeled single cup ( $80 \mathrm{~mL}$ volume). Another group of $50 \mathrm{~S}$. frugiperda $\mathrm{L}_{1}$ belonging to the same cohort were held separately in single cups as a control. Leaves collected from three-week-old untreated screenhouse maize plants were used as the food source for the larvae over a period of 12 days, when pupation started to occur. The young tender leaves were cut into pieces measuring $30 \mathrm{~cm}^{2}$ and were provided to the parasitized and control larvae. Every $24 \mathrm{~h}$, any remaining pieces of maize leaves that had not been consumed were removed from each cup containing either the parasitized or unparasitized S. frugiperda larvae. They were replaced immediately with fresh similarly sized pieces of leaves. In order to meet the food demand of unparasitized larvae, the number of pieces of maize leaf provided was increased as necessary from one to two pieces on the sixth to eighth day and from two to three pieces on the ninth to 12 th day.

The pieces of maize leaves that remained after $24 \mathrm{~h}$ were collected daily from each cup, labeled and dried separately in an oven at $70 \pm 10{ }^{\circ} \mathrm{C}$ for three days. At each renewal of feed, 40 pieces of maize leaves $\left(30 \mathrm{~cm}^{2}\right)$ were kept and dried in the same conditions to be used as a control. All the dried leaves were weighed using a precision laboratory analytical scale (COBOS ATY224 (Kyoto, Japan), Max $220 \mathrm{~g}$, Min $10 \mathrm{mg}$, Precision (d): $0.1 \mathrm{mg}$ ). The daily consumption of maize by the S. frugiperda larvae was calculated as the difference in dry weight between the entire pieces of the maize leaves that were offered to the larvae and the non-consumed parts of the leaves left by the larvae in their cups.

\subsection{Generation Time of C. luteum}

The daily observations of the development of parasitized larvae provided data to calculate the generation time of $C$. luteum under laboratory conditions. The time from the day of oviposition to cocoon formation and adult emergence was measured for all individuals.

\subsection{Statistical Analysis}

The mean dry weight of the pieces of maize leaves was used to calculate the food consumption of S. frugiperda larvae, without any transformation. The General Linear Model (GLM) with the repeated measures ANOVA procedure of SAS (version 9.4, Cary, NC, USA) was used to test the effect of the treatment and the time, as well as their interaction on the consumption of maize leaves by $S$. frugiperda larvae at the 0.05 alpha level. 


\section{Results}

\subsection{Generation Time of C. luteum}

From the 50 parasitized S. frugiperda larvae, 45 individuals of C. luteum completed their growth from egg to adult emergence and were used to assess the generation time of the parasitoid. The others reached the pupal stage but did not emerge. The female C. luteum wasp parasitized the exposed one-day-old $\mathrm{L}_{1}$ S. frugiperda by laying an egg inside its body. After hatching, the parasitoid larva fed inside the host, thereby affecting its growth. When the parasitoid larva completed its larval development, it emerged from the host (which caused its mortality) and built a white cocoon in which it pupated (Figure 1). The developmental period of the parasitoid from egg to pupal stage lasted eight to 10 days. The pupal stage also lasted eight to 10 days before the adult parasitoid emerged. The mean generation time of the 45 individuals having reached the adult stage was $16.71 \pm 0.14$ days (95\% CI: 16.42-17.00). The minimum generation time was 16 days and the maximum 20 days.

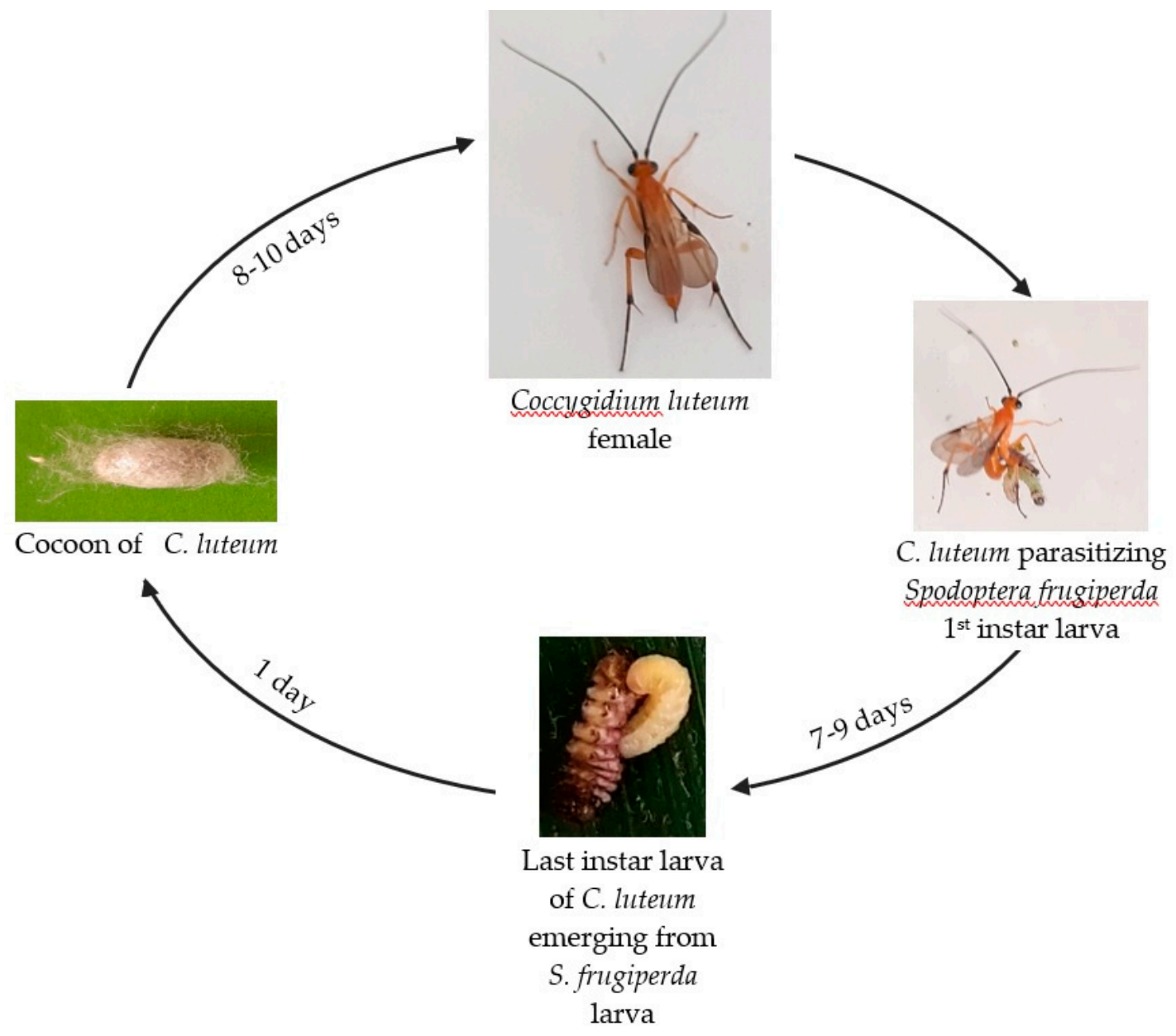

Figure 1. Generalized generation time of Coccygidium luteum.

\subsection{Leaf Consumption Rate of Parasitized and Unparasitized S. frugiperda Larvae}

The consumption rates of maize leaves by parasitized and unparasitized S. frugiperda larvae were significantly different $\left(\mathrm{F}_{(1,98)}=3155.01 ; p<0.001\right)$ (Figure 2A) (Table S1). Moreover, they were significantly affected by time (Day) $\left(\mathrm{F}_{(11,1078)}=284.99 ; p<0.001\right)$ and the interaction between treatment (larva status) and time $\left(\mathrm{F}_{(11,1078)}=310.38 ; p<0.001\right)$ (Table S2). 

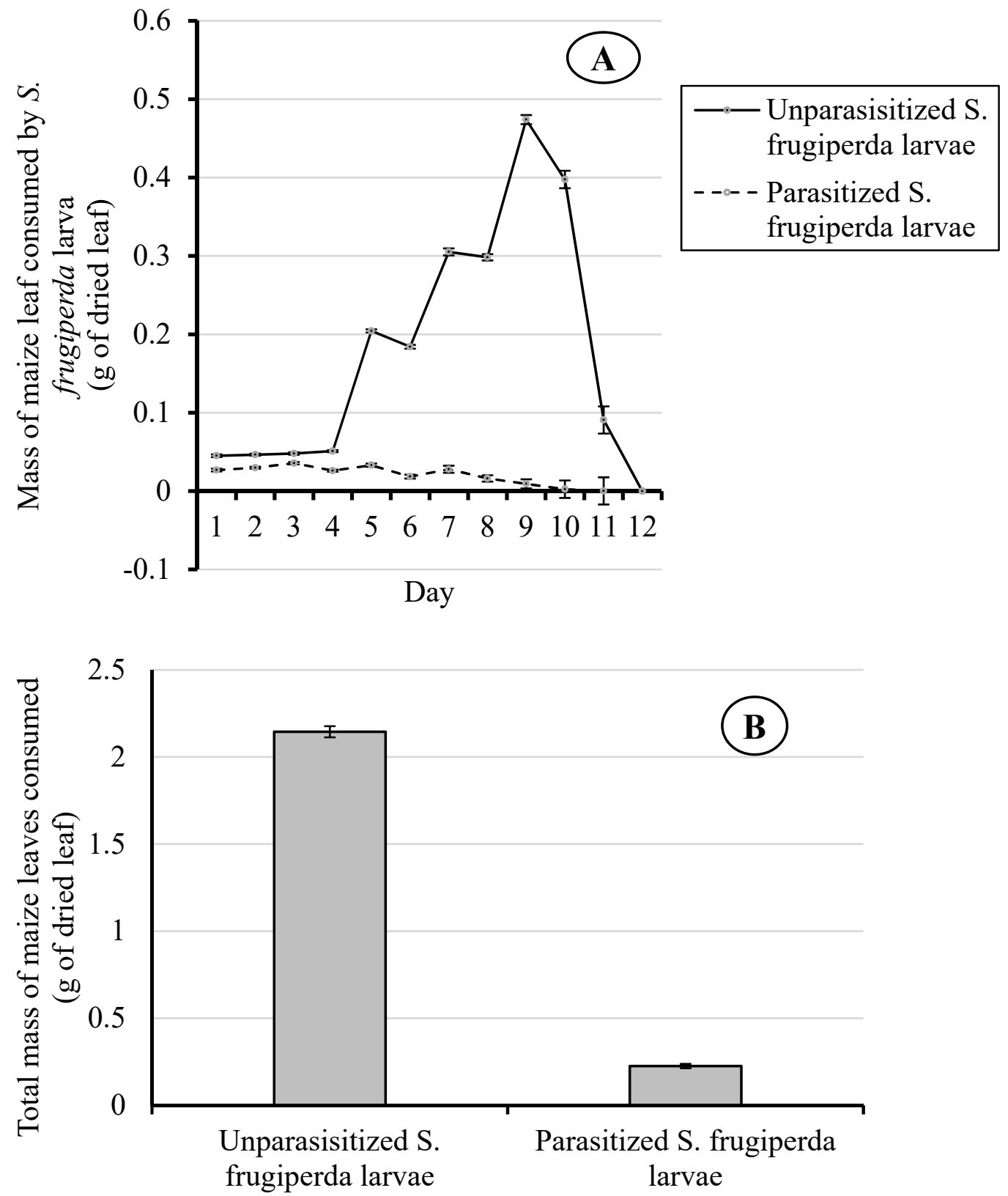

Type of larvae

Figure 2. Daily mass of maize leaf consumed (A) and total consumption of maize leaves (B) by the parasitized and unparasitized S. frugiperda larvae.

From day one to four of the experiment, the daily dry weight of maize leaves consumed by unparasitized S. frugiperda larvae $(0.045 \pm 0.002 \mathrm{~g}$ to $0.051 \pm 0.001 \mathrm{~g}$ dry wt. of leaf) was significantly higher $\left(\mathrm{F}_{(1,98)}=3155.01 ; p<0.001\right)$ than the amount taken by the parasitized larvae $(0.027 \pm 0.002 \mathrm{~g}$ to $0.036 \pm 0.002 \mathrm{~g}$ dry wt. of leaf) (Figure 2A). After day four, the leaf consumption by unparasitized $S$. frugiperda larvae increased quickly with time and it reached a peak on day nine $(0.473 \pm 0.006 \mathrm{~g}$ dry wt. of leaf) and then decreased until feeding ceased on day 12, as they went into pupation (Figure 2A). On day five, the consumption rate of the unparasitized S. frugiperda larvae went up sharply, consuming four times $(0.204 \pm 0.002 \mathrm{~g}$ dry wt. of leaf) the average daily mass of maize leaves they consumed during the first four days.

In contrast, the rate of consumption of maize leaves by the parasitized larvae was relatively stable from day one to day seven, and then decreased to zero by day 10 . On day nine, the leaf 
consumption by the parasitized larvae was estimated at $2 \%$ of that consumed by the unparasitized larvae $\left(\mathrm{F}_{(1,98)}=3155.01 ; p<0.001\right)$ (Figure $\left.2 \mathrm{~A}\right)$. The total weight of maize leaves consumed during the larval stage by the parasitized $S$. frugiperda $(0.226 \mathrm{~g})$ was $11 \%$ of that consumed by unparasitized $S$. frugiperda (2.145 g) (Figure 2B).

\section{Discussion}

This study provides partial data on the life cycle of C. luteum on S. frugiperda and describes its ability to reduce the leaf consumption rate of its lepidopteran host. Even though the laboratory conditions probably accelerated the development of the parasitoid compared to field conditions, it appears that the parasitoid could produce several generations in 90 days, which corresponds to the development cycle of most early-maturing maize varieties in West Africa [29]. During the larval stage of S. frugiperda, the endoparasitoid decreased the host's ability to feed on maize leaves and therefore its development. In total, feeding was reduced by $89 \%$ until the $S$. frugiperda larvae died. Other related studies have shown similar feeding reductions by koinobiont endoparasitoids in Spodoptera spp. For example, five parasitoids of S. frugiperda, namely Aleiodes laphygmae (Viereck), Campoletis sonorensis (Cameron), Chelonus insularis (Cresson), Cotesia marginiventris (Cresson) and Meteorus laphygmae (Viereck), decreased larval feeding by at least $80 \%$ [30]. This was also reported for the congeneric species Spodoptera littoralis (Boisduval), where food consumption and growth were significantly reduced by the endoparasitoids Hyposoter didymator (Thunberg) and Chelonus inanitus (Linnaeus) [31]. The effect of parasitism by C. luteum on $S$. frugiperda larvae could result from the different mechanisms associated with the parasitism process. Like all koinobiont endoparasitoids, C. luteum must overcome its host's defense mechanisms to survive. In general, the defense mechanisms developed by koinobionts are passive and/or active. In the case of passive defense, females coat their eggs with a layer of protein to protect them against the host's hemocytes or lay them in organs away from the circulation of hemocytes [32,33]. With an active defense mechanism, the endoparasitoid injects venom proteins or a virus during oviposition, in order to modify the behavior and damage the immune system of the host [34-37]. For example, another Braconidae, Chelonus blackburni (Cameron), is able to decrease significantly the number of hemocytes in a parasitized Helicoverpa armigera (Hübner) larva and affect its midgut, thereby reducing the leaf consumption rate of the host and leading to death [23].

For C. luteum, a venom is likely to be involved in the parasitism mechanism, due to the rapid reduction of the host leaf consumption rate from the day the larva is parasitized. In addition, the female parasitoid struggles with the host when ovipositing, thereby provoking in the parasitized larva an elevation of its dopamine level, which plays an important role in the retardation of larval growth [38].

The reduction of leaf consumption rate is a common phenomenon for endoparasitoid wasps [39,40], however, a critical aspect is how it could help reduce the damage caused by an herbivorous host. The $89 \%$ reduction in the leaf consumption rate of $S$. frugiperda larvae from our study suggests that, if high parasitism levels could be achieved in the field, limited damage from S. frugiperda could occur on maize plants, even when the consumption rate is time-dependent after being parasitized.

The field parasitism data obtained from Ghana due to this parasitoid [24] suggests that C. luteum could be a promising candidate for the augmentative biological control of $S$. frugiperda. However, this requires unravelling more detailed knowledge on the parasitoids' biology, such as the host stage and habitat specificity. It also requires the development of adapted and efficient mass rearing technologies. This is because the use of larval parasitoids as augmentative biological control agents is often hampered by prohibitive production costs. There are exceptions, such as the braconid Habrobracon hebetor (Say), which is used in several continents on various pests [41,42], but is produced cheaply on factitious hosts. It therefore remains to be seen whether $C$. luteum can be reared on hosts that can be mass produced at low cost. The cannibalistic behavior of $S$. frugiperda prevents its use in the mass rearing of larval parasitoids.

The abundance of C. luteum in Ghana also suggests the potential to be integrated in conservation biological control programmes. However, the environmental conditions, cropping systems and crop 
protection practices favoring the abundance of this and other parasitoids should be further investigated. This study has shown C. luteum to be able to parasitize early instar larvae, and therefore complement the action of other parasitoid species already present in Africa that target the egg stage or older larval stages $[18,43,44]$.

Finally, efforts should be made at the national, regional and international level to promote the use of biological approaches for the management of invasive pests in African agriculture, which is often dominated by chemical control, including the use of highly restricted pesticides $[17,45]$.

\section{Conclusions}

The results of this study are evidence that the endoparasitoid wasp, C. luteum, is able to reduce by up to $89 \%$ the leaf consumption rate of $S$. frugiperda on maize. Given that C. luteum is present in Western, Central, Eastern and Southern subregions of Africa, it could be considered as a potential parasitoid candidate for augmentative and conservation biocontrol strategies against $S$. frugiperda. The next steps are to assess whether an efficient and cost-effective rearing technique can be developed, and to carry out an assessment of environmental factors and cultural practices affecting field populations and the fitness of the parasitoid.

Supplementary Materials: The following are available online at http://www.mdpi.com/2075-4450/10/11/410/s1. Table S1: Significant tests of hypotheses for between subjects (treatment: parasitized and unparasitized S. frugiperda larvae) effects, Table S2: Significant univariate tests of hypotheses for within subject effects.

Author Contributions: Conceptualization, L.K.A. and V.A.C.; methodology, L.K.A. and S.A.M.; data collection, S.A.M., L.K.A., P.B., and R.G.; writing—original draft preparation, L.K.A.; writing-review and editing, M.K., V.A.C., I.R., and R.D.; project administration, R.D., M.K., V.A.C., and L.K.A.

Funding: This research was financially supported by the Department for International Development (DFID) and the Directorate-General for International Cooperation (DGIS), Netherlands, through CABI's Action on Invasives Programme. CABI is an international intergovernmental organisation, and we gratefully acknowledge the core financial support from our member countries (and lead agencies), including the United Kingdom (DFID), China (Chinese Ministry of Agriculture), Australia (Australian Centre for International Agricultural Research), Canada (Agriculture and Agri-Food Canada), Netherlands (DGIS) and Switzerland (Swiss Agency for Development and Cooperation). See http://www.cabi.org/about-cabi/who-we-work-with/key-donors/ for full details.

Acknowledgments: The authors are grateful to Plant Protection and Regulatory Services Directorate (PPRSD) of Ghana, especially Felicia Ansah-Amprofi and Ebenezer Aboagye for their collaboration.

Conflicts of Interest: The authors declare no conflict of interest.

\section{References}

1. Statistics Research and Information Directorate (SRID). Agriculture in Ghana: Facts and Figures 2015, 25th ed.; Report of MOFA (Ministry of Food and Agriculture); MOFA: Accra, Ghana, 2016; 113p.

2. Devi, S. Fall armyworm threatens food security in southern Africa. Lancet 2018, 391, 727. [CrossRef]

3. Sparks, A.N. A review of the biology of the fall armyworm. Fla. Entomol. 1979, 62, 82-87. [CrossRef]

4. FAO. Briefing Note on FAO Actions on Fall Armyworm in Africa; FAO: Rome, Italy. Available online: www.fao.org/3/BS183E/bs183e.pdf (accessed on 14 May 2019).

5. Wolfe, L.M. Why alien invaders succeed: Support for the escape-from-enemy hypothesis. Am. Nat. 2002, 160, 705-711. [CrossRef] [PubMed]

6. Colautti, R.; Ricciardi, A.; Grigorovich, I.; MacIsaac, H. Is invasion success explained by the enemy release hypothesis? Ecol. Lett. 2004, 7, 721-733. [CrossRef]

7. Murùa, G.; Virla, E. Population parameters of Spodoptera frugiperda (Smith) (Lep.: Noctuidae) fed on corn and two predominant grasses in Tucuman (Argentina). Acta Zool. Mex. 2004, 20, 199-210.

8. Goergen, G.; Kumar, P.L.; Sankung, S.B.; Togola, A.; Tamò, M. First report of outbreaks of the fall armyworm Spodoptera frugiperda (JE Smith) (Lepidoptera, Noctuidae), a new alien invasive pest in West and Central Africa. PLoS ONE 2016, 11, e0165632. [CrossRef]

9. Day, R.; Abrahams, P.; Bateman, M.; Beale, T.; Clottey, V.; Cock, M.; Colmenarez, Y.; Corniani, N.; Early, R.; Godwin, J.; et al. Fall armyworm: Impacts and implications for Africa. Outlooks Pest Manag. 2017, 28, 196-201. [CrossRef] 
10. Cock, M.J.W.; Beseh, P.K.; Buddie, A.G.; Cafá, G.; Crozier, J. Molecular methods to detect Spodoptera frugiperda in Ghana, and implications for monitoring the spread of invasive species in developing countries. Sci. Rep. 2017, 7, 4103. [CrossRef]

11. Nagoshi, R.N.; Goergen, G.; Tounou, K.A.; Agboka, K.; Koffi, D.; Meagher, R.L. Analysis of strain distribution, migratory potential, and invasion history of fall armyworm populations in northern Sub-Saharan Africa. Sci. Rep. 2018, 8, 3710. [CrossRef]

12. Montezano, D.G.; Specht, A.; Sosa-Gómez, D.R.; Roque-Specht, V.F.; Sousa-Silva, J.C.; Paula-Moraes, S.V.; Peterson, J.A.; Hunt, T.E. Host Plants of Spodoptera frugiperda (Lepidoptera: Noctuidae) in the Americas. Afr. Entomol. 2018, 26, 286-300. [CrossRef]

13. Baudron, F.; Zaman-Allah, M.A.; Chaipa, I.; Chari, N.; Chinwada, P. Understanding the factors influencing fall armyworm (Spodoptera frugiperda J.E. Smith) damage in African smallholder maize fields and quantifying its impact on yield. A case study in Eastern Zimbabwe. Crop Prot. 2019, 120, 141-150. [CrossRef]

14. Early, R.; González-Moreno, P.; Murphy, S.T.; Day, R. Forecasting the global extent of invasion of the cereal pest Spodoptera frugiperda, the fall armyworm. NeoBiota 2018, 40, 25-50. [CrossRef]

15. Feldmann, F.; Rieckmann, U.; Winter, S. The spread of the fall armyworm Spodoptera frugiperda in Africa-What should be done next? J. Plant Dis. Prot. 2019, 126, 97-101. [CrossRef]

16. Bateman, M.L.; Day, R.K.; Luke, B.; Edgington, S.; Kuhlmann, U.; Cock, M.J.W. Assessment of potential biopesticide options for managing fall armyworm (Spodoptera frugiperda) in Africa. J. Appl. Entomol. 2018, 142, 805-819. [CrossRef]

17. Kumela, T.; Simiyu, J.; Sisay, B.; Likhayo, P.; Mendesil, E.; Gohole, L.; Tefera, T. Farmers' knowledge, perceptions, and management practices of the new invasive pest, fall armyworm (Spodoptera frugiperda) in Ethiopia and Kenya. Int. J. Pest Manag. 2018. [CrossRef]

18. Sisay, B.; Simiyu, J.; Malusi, P.; Likhayo, P.; Mendesil, E.; Elibariki, N.; Wakgari, M.; Ayalew, G.; Tefera, T. First report of the fall armyworm, Spodoptera frugiperda (Lepidoptera: Noctuidae), natural enemies from Africa. J. Appl. Entomol. 2018, 142, 800-804. [CrossRef]

19. Yu, S.J. Insecticide Resistance in the Fall Armyworm, Spodoptera frugiperda (J. E. Smith). Pestic. Biochem. Phys. 1991, 39, 84-91. [CrossRef]

20. Farias, J.R.; Andow, D.A.; Horikoshi, R.J.; Sorgatto, R.J.; Fresia, P.; dos Santos, A.C.; Omoto, C. Field-evolved resistance to Cry1F maize by Spodoptera frugiperda (Lepidoptera: Noctuidae) in Brazil. Crop Prot. 2014, 64, 150-158. [CrossRef]

21. Togola, A.; Meseka, S.; Menkir, A.; Badu-Apraku, B.; Bouka, O.; Tamò, M.; Djouaka, R. Measurement of Pesticide Residues from Chemical Control of the Invasive Spodoptera frugiperda (Lepidoptera: Noctuidae) in a Maize Experimental Field in Mokwa, Nigeria. Int. J. Environ. Res. Public Health 2018, 15, 849. [CrossRef]

22. Prasanna, B.M.; Huesing, J.E.; Eddy, R.; Peschke, V.M. Fall Armyworm in Africa: A Guide for Integrated Pest Management, 1st ed.; CIMMYT: Mexico City, Mexico, 2018; 109p.

23. Sanap, Y.; Dawkar, V.V.; Giri, A.P.; Sen, A.; Pandit, R.S. Parasitism by Chelonus blackburni (Hymenoptera) affects food consumption and development of Helicoverpa armigera (Lepidoptera) and cellular architecture of the midgut. J. Asia Pac. Entomol. 2016, 19, 65-70. [CrossRef]

24. Agboyi, L.K.; Goergen, G.; Beseh, P.; Mensah, S.A.; Clottey, V.A.; Glikpo, R.; Buddie, A.; Cafà, G.; Offord, L.; Rwomushana, I.; et al. Parasitoid complex of fall armyworm, Spodoptera frugiperda in Ghana and Benin. Insects. Draft manuscript.

25. Van Noort, S. WaspWeb: Hymenoptera of the Afrotropical Region. 2019. Available online: www.waspweb.org (accessed on 16 June 2019).

26. Sharkey, M.J. Cladistics and tribal classification of the Agathidinae (Hymenoptera: Braconidae). J. Nat. Hist. 1992, 26, 425-447. [CrossRef]

27. Sharkey, M.J. Two new genera of Agathidinae (Hymenoptera: Braconidae) with a key to the genera of the New World. Zootaxa 2006, 1185, 37-51. [CrossRef]

28. Farahani, S.; Talebi, A.; Rakhshani, E.; Achterberg, C.; Sharkey, M. A contribution to the knowledge of Agathidinae (Hymenoptera: Braconidae) from Iran with description of a new species. Biologia 2014, 69, 228-235. [CrossRef]

29. Oluwaranti, A.; Fakorede, M.A.B.; Badu-Apraku, B. Grain yield of maize varieties of different maturity groups under marginal rainfall conditions. J. Agric. Sci. 2008, 53, 183-191. [CrossRef] 
30. Hoballah, M.E.; Degen, T.; Bergvinson, D.; Savidan, A.; Tamò, C.; Turlings, T.C. Occurrence and direct control potential of parasitoids and predators of the fall armyworm (Lepidoptera: Noctuidae) on maize in the subtropical lowlands of Mexico. Agric. For. Entomol. 2004, 6, 83-88. [CrossRef]

31. Morales, J.; Medina, P.; Vinuela, E. The influence of two endoparasitic wasps, Hyposoter didymator and Chelonus inanitus, on the growth and food consumption of their host larva Spodoptera littoralis. BioControl 2007, 52, 145-160. [CrossRef]

32. Schmidt, O.; Theopold, U.; Strand, M. Innate immunity and its evasion and suppression by hymenopteran endoparasitoids. BioEssays 2001, 23, 344-351. [CrossRef]

33. Godfray, H.C.J. Parasitoids. Encycl. Biodivers. 2007, 1-13. [CrossRef]

34. Yamanaka, A.; Hayakawa, Y.; Noda, H.; Nakashima, N.; Watanabe, H. Characterization of polydnavirus-encoded mRNA in parasitized armyworm larvae. Insect Biochem. Mol. Biol. 1996, 26, 529-536. [CrossRef]

35. Asgari, S.; Zareie, R.; Zhang, G.; Schmidt, O. Isolation and characterization of a novel venom protein from an endoparasitoid, Cotesia rubecula (Hym: Braconidae). Arch. Insect Biochem. 2003, 53, 92-100. [CrossRef]

36. Rivers, D. Venoms of Endoparasitic Wasps. In Encyclopedia of Entomology; Capinera, J.L., Ed.; Springer: Dordrecht, The Netherlands, 2008; pp. 4092-4093.

37. Fang, Q.; Wang, F.; Gatehouse, J.A.; Gatehouse, A.M.R.; Chen, X.; Hu, C.; Ye, G. Venom of parasitoid, Pteromalus puparum, suppresses host, Pieris rapae, immune promotion by decreasing Host C-Type Lectin Gene Expression. PLoS ONE 2011, 6, e26888. [CrossRef] [PubMed]

38. Noguchi, H.; Hayakawa, Y. Mechanism of parasitism-induced elevation of dopamine levels in host insect larvae. Insect Biochem. Mol. Biol. 1996, 269, 659-665. [CrossRef]

39. Beckage, N.E.; Riddiford, L.M. Effects of parasitism by Apanteles congregatus on the endocrine physiology of the tobacco hornworm Manduca sexta. Gen. Comp. Endocrinol. 1982, 47, 308-322. [CrossRef]

40. Beckage, N.E.; Riddiford, L.M. Developmental interactions between the tobacco hornworm Manduca sexta and its braconid parasite Apanteles congregates L. Entomol. Exp. Appl. 1978, 23, 139-151. [CrossRef]

41. Grieshop, M.J.; Flinn, P.W.; Nechols, J.R. Biological control of Indianmeal moth (Lepidoptera: Pyralidae) on finished stored products using egg and larval parasitoids. J. Econ. Entomol. 2006, 99, 1080-1084. [CrossRef]

42. Ba, M.N.; Baoua, I.B.; Kaboré, A.; Amadou, L.; Oumarou, N.; Dabire-Binso, C.; Sanon, A. Augmentative on-farm delivery methods for the parasitoid Habrobracon hebetor Say (Hymenoptera: Braconidae) to control the millet head miner Heliocheilus albipunctella (de Joannis) (Lepidoptera: Noctuidae) in Burkina Faso and Niger. BioControl 2014, 59, 689-696. [CrossRef]

43. Kenis, M.; du Plessis, H.; Van den Berg, J.; Ba, M.N.; Goergen, G.; Kwadjo, K.E.; Baoua, I.; Tefera, T.; Buddie, A.; Cafà, G.; et al. Telenomus Remus, a candidate parasitoid for the biological control of Spodoptera Frugiperda in Africa, is already present on the continent. Insects 2019, 10, 92. [CrossRef]

44. Sisay, B.; Simiyu, J.; Mendesil, E.; Likhayo, P.; Ayalew, G.; Mohamed, S.; Subramanian, S.; Tefera, T. Fall Armyworm, Spodoptera frugiperda Infestations in East Africa: Assessment of Damage and Parasitism. Insects 2019, 10, 195. [CrossRef]

45. Agboyi, L.K.; Djade, K.M.; Ahadji-Dabla, K.M.; Ketoh, G.K.; Nuto, Y.; Glitho, I.A. Vegetable production in Togo and potential impact of pesticides use practices on the environment. Int. J. Biol. Chem. Sci. 2015, 9, 723-736. [CrossRef]

(C) 2019 by the authors. Licensee MDPI, Basel, Switzerland. This article is an open access article distributed under the terms and conditions of the Creative Commons Attribution (CC BY) license (http://creativecommons.org/licenses/by/4.0/). 